\title{
Peru: integration, sectoral specialization and synchronization with international gross domestic product cycles
}

\author{
Mario D. Tello
}

ABSTRACT

This paper analyses the way the integration of trade, finance and sectoral specialization relates to the degree of synchronization between the gross domestic product (gdp) cycles of Peru and those of the 31 countries with which it trades most. The analysis is based on estimation of a system of simultaneous equations with panel data in which account is also taken of the repercussions of preferential trade agreements (ptas). The findings reveal robust two-way relationships between synchronization and financial integration, between the latter and trade integration, and between trade integration and sectoral specialization. ptas did not influence the different variables considered. This evidence suggests that greater trade integration in Peru would intensify the effects of partner countries' gdp cycles on Peruvian output in contexts like the 2008 and 2010 crises.

KEYWORDS

JEL CLASSIFICATION

AUTHOR
Economic integration, trade policy, financial policy, production specialization, preferential agreements, economic growth, business cycles, gross domestic product, mathematical modelling, Peru

F4, C33, O11

Mario D. Tello, centrum Católica and Department of Economics of the Catholic University of Peru. mtello@pucp.edu.pe 


\section{I}

\section{Introduction}

When it comes to considering the repercussions of international cycles and crises on an economy, one type of approach uses models, empirical regularities and synchronization of international business cycles between countries as its basis (e.g., Fidrmuc and Korhonen, 2009; Backus, Kehoe and Kidland, 1992), while another type estimates the effects of external crises, volatility or shocks on economic growth or performance (e.g., Edwards, 2007; Aghion and Banerjee, 2005; De Gregorio and Lee, 2003; Loayza and Hnatkovska, 2003). In this latter tradition, the author (Tello, 2009b) estimated the impact of external shocks and preferential trade agreements (PTAs) ${ }^{1}$ on real per capita gross domestic product (GDP) growth in the Peruvian economy over the period from 1950 to 2007.

The study concluded that external shocks did not alter Peru's long-run economic growth during that period, although they did affect per capita GDP and its annual rate of change in the short term. The strength and duration of these impacts depended on the handling of stabilization policies (or programmes) and on the size of the external shocks. Again, the PTAs implemented

$\square$ This paper was prepared within the Trade and Poverty in Latin America (COPLA) project framework, with financing from the United Kingdom Department for International Development (DFID) through the Overseas Development Institute (ODI). The author is grateful to Gabriel Rodríguez for his collaboration on a cOPLA report on which the present study is based. He is also grateful for the support of Hans Lavilla, Carmen Zeña and Jairo Flores and for the comments of the anonymous cepal Review referee.

1 A preferential trade agreement is defined as a set of instruments that countries use for the purpose of reducing or removing restrictions on commerce in traded goods, services and factors. These agreements can be of four kinds: (i) unilateral, where an economy unilaterally reduces its trade restrictions; (ii) bilateral or regional, where two or more countries agree to reduce trade restrictions discriminately (as countries that are not members of the agreement are excluded from its benefits) and reciprocally; (iii) generalized system of preferences, where a country agrees to reduce its trade restrictions discriminately for a group of countries, without requiring the reductions to be matched by them; and (iv) multilateral agreement, this being a regional agreement covering a large number of countries, such as the member countries of the World Trade Organization (WTO). since the 1970s have not contributed to higher rates of productivity and per capita output growth. The effects of these agreements have generally been limited by the type of development models implemented and by the complete failure to reduce non-tariff trade barriers. These trade restrictions have continued to limit access to the export markets of the country's main trading partners, even though tariff barriers have progressively come down as a result of these agreements, which are variously unilateral, bilateral or regional, and multilateral in nature.

The present study is an exploratory one, and it addresses the subject of external crises. Following the first approach, it analyses the effects of (trade and financial) integration, sectoral specialization levels and PTAs on the degree of synchronization between the GDP cycles of Peru's main trading partners and Peru's own GDP. This approach is thus used to evaluate the effect in terms of the correlation of partner countries' GDP cycles deriving from a greater or lesser flow of goods and capital or from the degree of differentiation between these countries' sectoral structures. The main conclusion from the body of evidence reported for the 1982-2006 period is that the international cycles arising because of internal shocks in leading trade partners have affected Peru's real GDP cycles. In contrast, a second important conclusion from the estimations is that the PTAs implemented by Peru during the period considered have not had a statistically significant influence on the degree of synchronization between Peru's GDP cycles and those of its main trading partners.

This study consists of five sections. Section II summarizes the theoretical aspects supporting the interrelationship between the degree of synchronization of GDP cycles, trade and financial integration, and the degree of sectoral specialization between the trading countries. Section III describes the specification to be estimated and lists the variables to be considered and the information sources used. Section IV summarizes the findings in the form of a hypothesis, given the exploratory nature of the study. Section V sets out the conclusions. References are given at the end of the paper. 


\section{II}

\section{Synchronization of cycles and relationship to the degree of integration in trade, finance and sectoral specialization: conceptual considerations}

Intuitively, the more closely countries are integrated, the more strongly business cycles will be transmitted between them. Integration may occur through trade in goods and services or through flows of capital and financial assets. However, this intuitive argument is not theoretically sound. Furthermore, there is a striking discrepancy between the empirical evidence for the degree of output "synchronization" or "co-movement" 2 between countries and the theoretical models that seek to explain this degree of synchronization or movement.

Calderón, Chong and Stein (2007), based on Stockman (1988), summarize some of the theoretical arguments ${ }^{3}$ using the components of the correlation coefficient for the real GDP of two countries, $Y_{i}$ and $Y_{j}$.

$$
\begin{gathered}
\rho_{i j}=\sigma_{k} \cdot\left(\sigma_{i} \cdot \sigma_{j}\right)^{-1 / 2} \cdot \sum_{k=1}^{N_{s}} w_{k i} w_{k j}+ \\
\sigma_{i j} \cdot\left(\sigma_{i} \cdot \sigma_{j}\right)^{-1 / 2} ; \\
w_{k i}=Y_{k i} / Y_{i} ; w_{k j}=Y_{k j} / Y_{j}
\end{gathered}
$$

where $\rho_{i j}$ is the correlation coefficient for the GDP cycles of countries $i$ and $j$, and $N_{s}$ is the number of sectors.

The first addend of (1.1) reflects the contribution made to the correlation coefficient or degree of cycle synchronization between two countries by the impact of specific shocks (assumed to be equal for both countries) in industry or sector $k$. These "random" shocks are independent of other sectors and of time; $\sigma_{k}$ is the variance of shocks that are the same for all industries $k$;

\footnotetext{
2 This is measured by Pearson's coefficient of correlation between the GDP of two countries or a group of countries.

${ }^{3}$ Other summaries of the theoretical models for the relationship between synchronization of international cycles and trade and financial integration can be found in Ambler, Cardia and Zimmermann (2002); Canova and Dellas (1993); Baxter (1995); Kollman (2001); Kose and Yi (2002 and 2001).
}

$\sigma_{i}$ and $\sigma_{j}$ are the variances of each country's GDP; and $w_{k i}$ and $w_{k j}$ are the share of sector $k$ in each country's total GDP. The second addend reflects the contribution made to the degree of cycle synchronization in two countries by aggregate and country-specific shocks. $\sigma_{i j}$ is the covariance of these shocks between the two countries, and $\sigma_{i j} \cdot\left(\sigma_{i} \cdot \sigma_{j}\right)^{-1 / 2}$ is the correlation resulting from the two countries' shocks.

Standard comparative advantage theory predicts that the more highly the countries possessing such an advantage are integrated, the more they will specialize, and trade will be essentially intersectoral (i.e., goods and services from different industries will be exchanged). Thus, changes in $w_{k i}$ are expected to correlate negatively with changes in $w_{k j}$; also negative, accordingly, will be the contribution to the degree of synchronization of the first component resulting from industry-specific shocks. This implies that the higher the level of integration owing to inter-industry trade, the less synchronized the two economies' GDP cycles will be.

Conversely, if trade is dominated by competitive advantages, and thus by intra-industry commerce, greater integration will mean a higher degree of association between sectoral shares and thus greater synchronization of the two countries' GDP cycles. ${ }^{4}$ In this case, the correlation of shocks between the countries would reinforce the effects of sector-specific shocks. These opposing signs between the degree of synchronization and that of integration depend on whether the latter induces a higher or lower degree of intersectoral specialization. ${ }^{5}$

Insofar as financial integration also has consequences for sectoral specialization, this too will affect the degree of synchronization. Thus, Kalemli-Ozcan, Sørensen

\footnotetext{
${ }^{4}$ Krugman (1993) and Kose and Yi (2001), among many others, have developed this line of theory.

${ }^{5}$ Specialization in sectors is consistent with both intra- and interindustry trade. In the first case, it involves a more refined kind of specialization, such as vertical specialization (Kose and Yi, 2001) within the same industry.
} 
and Yosha (2001 and 2003) argue that while industrial specialization brings a number of benefits to an economy, if output is not insured against the risks of this specialization then the GDP variance resulting from it will entail losses of welfare that may be greater than the benefits. Although specific types of insurance (catastrophe insurance with futures contracts, for example) may provide a way of offsetting these risks, it is by geographically diversifying their income sources through the international capital market that countries and regions insure themselves against the risk of specialization. Consequently, if interregional and international capital is well integrated, countries and regions can insure against industry/sector shocks and thereby position themselves to better exploit the comparative or competitive advantages they possess.

As in the case of goods and services trade integration, the greater the degree of financial integration, the lower the degree of synchronization will be if the trade between countries is inter-industrial, and the higher it will be when trade is intra-industrial. The synchronization of cycles between countries is said to be "asymmetrical" in the first case and "symmetrical" in the second.

The second component contributing to the degree of synchronization is the one resulting from countryspecific (and not sector- or industry-specific) shocks. The degree of trade and financial integration can also affect this component. Thus, demand shocks in one country can have spillovers that increase the covariance of countries' GDP. Such increases in demand in country $i$ entail greater demand for goods from country $j$; the higher the degree of integration, the greater the demand effect thus transmitted to other countries will be. Consequently, this second component (when $\sigma_{i j}>0$ ) can offset and even exceed the effects of the first component if the advantages are comparative in nature and reinforce them if the advantages are competitive. In these cases, increases in trade integration will lead to increases in the synchronization of the two economies' GDP cycles.

Frankel and Rose (1998) add that policy coordination between regions heightens the effects of integration on the synchronization of international cycles. Coe and Helpman (1995) and Lichtenberg and Van Pottelsberghe (1998) stress the transmission of productivity shocks between countries. Transmission of such shocks by technological diffusion, foreign investment flows and technology sources is intensified by trade and financial integration.

A second group of theoretical and empirical arguments regarding the interrelationships between integration, sectoral specialization and synchronization were made by Backus, Kehoe and Kidland (1993), who discovered what is known as the "quantity anomaly". In a world free of market distortions and with free movement of factors and access to trade in goods, positive shocks that increase returns in a country or a sector of it entail factor and asset movements that result in negative GDP correlations. Kose and Yi (2006, 2002 and 2001) show that models of international cycles cannot replicate empirical evidence on the degree of synchronization between countries. These models predict that the more trade or financial integration there is, the lower the degree of GDP synchronization between countries will be.

Because of this discrepancy between the empirical evidence and theoretical models, some of the literature has concentrated on introducing "factors or conditions" into output or markets such that they can account for the degree of synchronization between countries. One direct channel, mentioned earlier, is the degree of sectoral specialization. Thus, the more the structures of countries' production sectors differ, the less their GDP cycles will be synchronized. Two indirect channels, also described earlier, operate through the effects of trade and financial integration on sectoral specialization.

The direct channels of trade and financial integration are taken from the standard models of international trade, and introduce some changes of factors or conditions into output and markets. Thus, for example, Kose and Yi (2001) introduce trade within a single industry or sector in goods deriving from "stages in the production process", and obtain a higher degree of synchronization when "trade intensity" between countries increases. Heathcote and Perri (2002a and 2002b), Calvo and Mendoza (2000) and Mendoza (2002) show that distortions in the international capital market (such as limitations on the ability to lend or borrow capital internationally, or liquidity constraints affecting investors) can increase the degree of GDP synchronization between countries.

There is a fairly plentiful empirical literature dealing with the effects of trade and financial integration and of the degree of specialization on GDP synchronization between countries. Among the most recent studies, that of Calderón, Chong and Stein (2007) stands out. This uses a sample of 147 countries in the 1960-1999 period and employs cross-sectional and panel data econometric techniques, concluding that: (i) increases in integration or the intensity of goods trade induce greater synchronization of GDP cycles between countries; (ii) the repercussions of trade intensity are greater for the sample of developed countries than for the sample of developing countries; and (iii) the repercussions of trade intensity are more marked for countries with similar sectoral structures. 
Second, Imbs (2004) works with quarterly data on 24 countries (six developing, including Peru, and 18 developed) for the 1980-1999 period and with a system of four simultaneous equations, and finds as follows: (i) specialization patterns have substantial effects on economic cycles between countries, which are independent of the degree of trade and financial integration; (ii) in the presence of a variety of financial integration measures, regions with a high level of financial integration present greater synchronization of GDP cycles despite their sectoral specialization; and (iii) if trade is intra-industrial, there are also increases in GDP synchronization between countries.

Lastly, García-Herrero and Ruiz (2008), working with a sample of 109 countries ( 88 of them developing) for the 1990-2004 period and with a system of four simultaneous equations, estimate the incidence of trade, financial and specialization integration on the synchronization of Spanish GDP cycles with those of the country's trading partners. These authors find that: (i) the intensity of trade and the similarity between the sectoral structures of Spain and its trading partners positively affect GDP cycle synchronization between Spain and its trading partners, and (ii) notwithstanding this, financial integration negatively affects synchronization. This finding is consistent with standard models of international cycles.

To sum up, the theoretical considerations and empirical evidence described in this section indicate that while the synchronization of an economy's GDP cycles with those of the countries with which that economy trades goods, services and financial assets is associated with the degree of integration between the countries' sectoral structures in terms of trade, finance and specialization, these relationships are not straightforward but have direct and indirect components and depend on other factors, such as the sources determining trade, distortions in goods, services and financial markets, and the existence of different stages in the production process.

The purpose of the present study is to empirically identify these associations and interrelationships for the Peruvian economy in the 1982-2006 period. To do this, it will specify a system of simultaneous equations similar to that of the two earlier studies (Imbs, 2004; García-Herrero and Ruiz, 2008) and add the effects of PTAs. These agreements contribute to trade integration between their member countries and are expected to have the same effects on GDP synchronization as on trade integration.

\section{III}

\section{Specification of the system of equations and information sources}

\section{The model: specification and basic variables}

Theoretical considerations (described in the previous section) have been formalized and summarized by Imbs (2004) and García-Herrero and Ruiz (2008) using the following system of equations:

$$
\begin{gathered}
\rho_{j t}=\alpha_{0}+\alpha_{1} \cdot T_{j t}+\alpha_{2} \cdot S_{j t}+ \\
\alpha_{2} F_{j t}+X_{1} \cdot \phi_{1}+\varepsilon_{1 j t} ; \\
T_{j t}=\beta_{0}+\beta_{1} \cdot S_{j t}+\beta_{2} \cdot F_{j t}+X_{2} \cdot \phi_{2}+\varepsilon_{2 j t} ; \\
F_{j t}=\delta_{0}+\delta_{1} \cdot \rho_{j t}+\delta_{2} \cdot T_{j t}+X_{3} \cdot \phi_{3}+\varepsilon_{3 j t} ; \\
S_{j t}=\gamma_{0}+\gamma_{1} \cdot T_{j t}+\gamma_{2} \cdot F_{j t}+X_{4} \cdot \phi_{4}+\varepsilon_{4 j t} ; \\
j=1,31 ; t=1982-2006
\end{gathered}
$$

where $\rho_{j t}, T_{j t}, S_{j t}$ and $F_{j t}$, termed "basic variables", are the degree of GDP synchronization (as measured by the correlation coefficient for GDP cycles), integration of trade in goods, financial integration and the degree of sectoral specialization, respectively, between Peru and its trading partner, country $j$, in year $t$; the matrix $X_{i}$ is formed by the control variables for each equation $i$, and $\varepsilon_{i j t}$ is the error of equation $i$, country $j$, year $t$. This system captures direct and indirect effects and the theoretical interdependences between the degree of GDP cycle synchronization, financial and trade integration, and sectoral specialization.

Equation (2.1) captures the total effects of these last three factors and of the control variables on the degree of GDP synchronization. Equations (2.2), (2.3) and (2.4) capture the indirect effects of the degrees of integration in finance, trade and sectoral specialization 
and the interdependences between these variables. Thus, in equation (2.2), if trade between Peru and country $j$ is dominated by inter-industry trade (and there are no shocks in the countries), then an increase in specialization will generate a higher degree of goods integration and vice versa. In equation (2.4), similarly, if trade is dominated by inter-industry flows, then a higher degree of goods integration will entail greater sectoral specialization. If the sign were the opposite, then trade between Peru and country $j$ would be dominated by intra-industry flows.

The degrees of financial and trade integration may be complementary or substitutive. They will be complementary if financial flows or foreign investment go to the export sectors where Peru has comparative advantages. In this case, the signs of the coefficients of the variables $F_{j t}$ and $T_{j t}$ in equations (2.2) and (2.3), respectively, will be positive. These degrees will be substitutes if financial flows and foreign investment go to sectors competing with imports. In this case, the signs of the coefficients will be negative. The degree of financial integration can also affect the degree of sectoral specialization, as noted in the previous section. Its effect will be positive if financial integration induces intra-industry specialization and negative if financial integration induces inter-industry specialization.

The Hodrick-Prescott (1997) filter was used to measure the GDP cycles of Peru and its partner countries. ${ }^{6}$ The degree of synchronization, $\rho_{j t}$ is Pearson's correlation coefficient calculated from 1970 to year $t$ between the estimated real GDP cycle of partner country $j$ and the estimated real GDP cycle of Peru.

Two indicators are used for the degree of trade integration:

$$
\begin{gathered}
T_{1 j t}=N_{t}^{-1} \cdot \sum_{i=1970}^{t}\left(X_{j i}+M_{j i}\right) /\left(Y_{j i}+Y_{i}\right) ; \\
T_{2 j t}=\left(2 \cdot N_{t}\right)^{-1} \cdot \sum_{i=1970}^{t}\left(X_{j i}+M_{j i}\right) \cdot Y_{w i} / \\
{\left[\left(Y_{j i}\right) \cdot\left(Y_{i}\right)\right] ; \quad t \leq 2006}
\end{gathered}
$$

\footnotetext{
${ }^{6}$ With the parameter $\lambda=100$, which has the role of penalizing the variability of the trend component of the GDP variable. Estimates were also produced using another two measures of cycles: the GDP variation rate and the errors of a quadratic regression for GDP in Peru and its partner countries. The results obtained using these indicators do not alter the conclusions of the present study.
}

where $N_{t}$ is the number of years from 1970 to year $t ; X_{j i}$ and $M_{j i}$ are the values of exports from Peru to country $j$ and imports by Peru from country $j$, respectively, in year $i(\leq t) ; Y_{j i}$ is the dollar GDP of country $j$ in year $i ; Y_{i}$ is the dollar GDP of Peru in year $i$; and $Y_{w i}$ is the dollar GDP of the world in year $i$. The first indicator represents the value of goods trade flows relative to the GDP of Peru and its partner countries, and the second represents this value relative to world GDP.

Where the degrees of financial integration and specialization are concerned, two indicators are also used for each degree. These are:

$$
\begin{gathered}
F_{1 j t}=N_{t}^{-1} \cdot \sum_{i=1982}^{t} I_{j i} /\left(Y_{j i}+Y_{i}\right) ; \\
F_{2 j t}=N_{t}^{-1} \cdot \sum_{i=1982}^{t} I_{j i} ; \\
S_{i j t}=-N_{t}^{-1} \cdot \sum_{i=1970}^{t} \sum_{k=1}^{5} / S_{k}-S_{k j} / \\
S_{2 j t}=-\sum_{i=1970}^{t} N_{t}^{-1} \cdot / \sum_{k=1}^{5} / S_{k}-\sum_{k=1}^{5} S_{k j} /
\end{gathered}
$$

where $I_{j i}$ is the stock of foreign investment from country $j$ in Peru in year $i$, and $s_{k}$ and $s_{k j}$ are the real GDP shares of sector $k$ in Peru and in country $j$. The sectors are: agriculture, mining, manufacturing, construction and services. The numbering $N_{t}$ starts in 1982 for the two investment indicators and in 1970 for all the other variables. Sectoral GDP figures were available up to $2006 .{ }^{7}$

The indicators for the degree of financial integration represent the relative size (relative, that is, to the GDP of Peru and its trading partners) and the absolute size of the stock of foreign investment from Peru's trading partners. At the same time, the two indicators of sectoral specialization represent the degree of similarity in sectoral structures between Peru and its partner countries. A smaller difference in the degree of sectoral specialization between Peru and country $j$ implies an $S_{j t}$ value close to zero (0) and a greater difference in this degree implies negative values well below zero (0) for $S_{j t}$.

\footnotetext{
${ }^{7}$ Indicators for the four basic variables are given in table A1 of the annex.
} 


\section{Preferential trade agreements (ptas)}

The variables representing PTAs and included as control variables in matrix $X_{i}$ are of three types for bilateral or regional agreements and two types for unilateral and multilateral generalized system of preferences (GSP) agreements. For the first two types of agreements, the variables are:

- $A_{j}=$ discrete variable taking the value one (1) for every year considered, always provided Peru and country $j$ are members of agreement $A$, failing which it will take the value zero (0). This variable is meant to capture the "country" effect on the dependent variable without taking the agreement into account.

- $D A_{j t}=$ discrete variable taking the value one (1) if Peru and country $j$ are members of agreement $A$ during period $t$ of the agreement's implementation, failing which it will take the value zero (0). This variable is meant to capture the "trade creation" effect of agreement $A$ on the dependent variable. In theory, this effect ought to be similar to the effect of the degree of trade integration.

- $T A_{j t}=$ variable taking the value of the time variable (numbering from 1 to 25 representing the years from 1982 to 2006) in the period of implementation of Peru's agreement $A$ and zero (0) in other periods. This variable is meant to capture the permanent effect of the agreement on the trend of the dependent variable.

The variables for the other three types of agreement are:

- $A_{t}=$ binary variables taking the value one (1) in the implementation period of the unilateral/multilateral agreement or GSP agreement granted to Peru and zero (0) in other periods. This variable is meant to capture the temporary effect of the agreement on the level of the dependent variable.

- $T A_{j t}=$ variable taking the value of the time variable (numbers 1 to $T$ representing the years from 1982 to 2007) in the period of implementation of Peru's agreement $A$ and zero (0) in other periods. This variable is meant to capture the permanent effect of the agreement on the trend of the dependent variable.

The names of the agreements $A$ considered are: ${ }^{8}$

- AC, Andean Community, initiated in 1970 and in force since 1971. Peru withdrew temporarily in

\footnotetext{
8 A detailed listing of characteristics of the preferential agreements considered can be found in Tello (2009a).
}

1993 before rejoining in 1997. In accordance with the notation for trade agreements, the variables corresponding to this agreement are $\mathrm{AC}, \mathrm{DAC}$ and TAC.

- ACAR, partial scope economic complementation agreement (ECA) between the AC (excluding the Plurinational State of Bolivia) and Argentina; in force since 2001. The variables corresponding to this agreement are ACAR and DACAR.

- ACBR (ECA 39), partial scope economic complementation agreement between the $\mathrm{AC}$ and Brazil in 1999. The variables corresponding to this agreement are ACBR, DACBR, TACBR.

- ECA 38, the Chile-Peru Economic Complementation Agreement, in force since 1998. The variables corresponding to this agreement are $\mathrm{CHI}$, DCHI, and TCHI

- atPdea, the Andean Trade Promotion and Drug Eradication Act, which is a generalized system of preferences granted by the United States to the member countries of the AC. These preferences were initiated in the Andean Trade Preference Act (ATPA), a preferential trade agreement signed by the States of the AC in 1992, and continued in expanded form in 2001 with the ATPDEA; consequently, this agreement takes values of one (1) from 1993 onward. The variables corresponding to this agreement are ATPDEA and TATPDEA.

- UA, unilateral arrangement applied during the liberalizing period of the Peruvian economy, running from 1991 to 2007. This variable also captures some of the liberalizing policies or structural reforms that were implemented in this period. The variables corresponding to this arrangement are UA and TUA.

- MA, Uruguay Round multilateral agreement applied since 1994. The variables corresponding to this agreement are MA and TMA.

The additional control variables for the degree of synchronization equation, $X_{1}$, are:

- Dif-Infla ${ }_{j t}=$ the absolute value of the inflation difference between Peru and its partner country $j$ in period $t$. This variable is meant to capture the effect of economic policy convergence between the two countries on the degree of GDP synchronization between them.

Binary variables are also introduced to capture the effects of countries being members of geographical regions. These include North America, Central America, the Southern Cone, the European Union, Asia, and other America. This group of variables is similar to the variable $A_{j t}$. The effect of the geographical area of the Andean region is captured by the variable AC. 


\section{Control variables}

The control variables for the rest of the $X_{i}$ equations $(i=2,3,4)$, as the case may be, are:

- $Y_{t}=$ the real GDP (in 1990 dollars) of Peru. This variable is meant to capture the effect of domestic demand or growth on the dependent variables of equations (2.2), (2.3) and (2.4). This effect may be pro-trade (positive sign) or anti-trade (negative sign). ${ }^{9}$ Equation (2.3) also includes the per capita GDP, $Y p$, of the partner country as a factor incentivizing foreign investment in Peru. The theoretically expected sign of this coefficient is positive.

- Dif- $Y p_{j t}=$ the absolute value of the difference in real per capita GDP between Peru and partner country $j$ in period $t$. This variable is meant to capture the effect of differences in development level on the dependent variables of equation (2.2), $T_{j t}$ and equation (2.3), $F_{j t}$.

A positive sign for the Dif- $Y p_{j t}$ coefficient in the equation for the degree of goods trade integration, $T_{j t}$, means that the source of the trade is comparative advantage and inter-industry trade predominates. A negative sign for the coefficient means that the source of the trade is competitive advantage and it is intra-industry trade that predominates. An alternative interpretation, which produces opposing signs, is the possibility that the divergence in development levels may increase the diversification of markets, thus reducing the degree of integration of each country $j$.

In the case of the equation for the degree of financial integration, $F_{j t}$, whose indicators measure the relative and absolute size of the stock of foreign investment from country $j$, the effect of the Dif- $Y p_{j t}$ variable is open to two possible interpretations. In the first, much as in the case of the degree of trade integration, the Dif- $Y p_{j t}$ variable indicates the source of international advantages (comparative or competitive). Thus, a positive sign for the coefficient of this variable implies that the size of the stock of foreign investment from country $j$ in Peru is mainly determined by the exploitation of the resources from which Peru's comparative advantages derive. A negative sign means that exploitation takes place in sectors with a competitive advantage. The second interpretation, as a source of attraction for foreign investment, is caused by the divergence in the countries' development level. ${ }^{10}$

\footnotetext{
9 The estimates of equation (2.3) also include per capita GDP, $Y p$, which represents the development level of Peru as a pull factor for foreign investment. The theoretical sign expected of this coefficient is positive. 10 This argument was made by Lucas (1990).
}

Thus, the greater the difference between Peru's per capita GDP and the partner country's, the less attractive the country will be to foreign investors, and vice versa. The evidence given in table 1 shows that the negative sign consistent with this latter interpretation predominates.

In the case of equation (2.4) for the degree of similarity in sectoral structure, the sign theoretically expected for the impact of Dif- $Y p_{j t}$ is positive. In other words, the smaller the difference in development level between Peru and the partner country, the smaller the difference in the countries' sectoral structures will be.

$$
\begin{aligned}
\operatorname{SIMILAR}_{j t} & =1-\left(Y_{j t}+Y_{t}\right)^{-2} \cdot\left(Y_{t}^{2}+Y_{j t}^{2}\right) \\
-\infty & <\operatorname{SIMILAR}_{j t} \leq 1 / 2
\end{aligned}
$$

The $S I M I L A R_{j t}$ variable represents the degree of similarity (in terms of GDP) between Peru and partner country $j$. The sign of the coefficient for this variable in equations (2.2) and (2.3) is similar to that of the per capita GDP differential, insofar as it represents (comparative or competitive) international advantages. Intuitively, the sign of the coefficient in equation (2.4) would be expected to be positive. Similarity between economies that trade with each other also implies similarity in the degree of sectoral specialization.

$R E R b_{j t}=$ the bilateral real exchange rate of Peru with country $j$ in period $t$, where $R E R_{j t}=\left[I E_{i j t} * C P I_{j t}\right] /$ $C P I_{i t} ; E_{i j t}$ is the nominal bilateral exchange rate of Peru with country $j$, defined as the price of the currency of country $j$ in terms of the currency of Peru; $I E_{i j t}$ is the exchange-rate index with base year 2000, and $I E_{i j t}=$ $\left(E_{i j t} / E_{i j 2000}\right) * 100 ; C P I_{i t}$ is the consumer price index of Peru in period $t$ with base year 2000; and $C P I_{j t}$ is the same index for country $j$.

The coefficients of this variable represent the combination of relative supply and demand price effects on the degrees of trade and financial integration. A positive coefficient means that the supply price effect has prevailed over the demand effect, and both degrees of integration would increase with a rise in $R E R b_{j t}$ if foreign investment went to export sectors. A negative sign for the coefficient means that the demand price effect is the one that predominates, and both degrees would decrease with increases in $R E R b_{j t}$ if foreign investment went to export sectors.

$A R A N_{j t}=$ the (percentage) simple or weighted average most-favoured-nation (MFN) tariff applied by importing country $j$ to Peru's export goods in period $t$. This variable represents the trade barriers put up by partner countries. Theory says that the sign of the coefficient 
of this variable for the two degrees of integration will be negative provided that foreign investment flows go to export sectors.

$D I S T_{j t}=$ the distance in kilometres between the capitals of Peru and partner country $j$. The theoretical sign is similar to that for tariffs.

Lastly, the following characteristics of partner countries $j$ trading with or investing in Peru were also introduced as control variables for equations (2.2), (2.3) and (2.4):

- $L A N G_{j}=$ dummy taking the value one (1) if partner country $j$ has the same official language as Peru and zero (0) in all other cases. The theoretical sign for the coefficient of this variable is positive in each of the three equations.

- $B O R D_{j}=$ dummy taking the value one (1) if partner country $j$ shares a border with Peru and zero $(0)$ in all other cases. The theoretical sign expected for the coefficient of this variable is also positive for all three equations.

- $C O L_{j}=$ dummy taking the value one (1) if partner country $j$ has had a colonial relationship with Peru and zero (0) in all other cases. The sign for the coefficient of this variable is the same as in the two previous cases.

- $I S L_{j}=$ dummy taking the value one (1) if partner country $j$ is an island and zero (0) in all other cases. ${ }^{11}$ The theoretical sign for the coefficient of this variable is negative.

11 The partner countries deemed to be islands are Australia, New Zealand, Japan and Singapore.
- $S E A_{j}=$ dummy taking the value one (1) if partner country $j$ is surrounded by land (practically landlocked) and zero (0) in all other cases. The theoretical sign expected for this variable as regards the degrees of trade and financial integration is negative.

- $A R E A_{j}=$ the size of partner country $j$ in square kilometres.

A number of information sources were drawn upon for the variables used. Real GDP (in 1990 dollars) and sectoral GDP were taken from UNCTAD (2009). Data on the stock of foreign investment come from INEI (2009). The data on the characteristics of the countries and bilateral exchange rates were taken from Tello (2009a). Export and import flows are from United Nations (2009).

\section{Initial hypotheses}

Figure 1 summarizes the theoretical hypotheses specified in the system of equations.

In the case of the Peruvian economy, whose export structure is dominated by commodities ${ }^{12}$ and whose main trading partners are industrialized countries, ${ }^{13}$ the expectation is that, in the absence of country shocks, the theoretical relationships deriving from inter-industry trade and comparative advantages will predominate. Specifically, the indicators for degrees of specialization,

12 In $2007,84 \%$ of all exports by value were commodities and $62 \%$ were mining products (Tello, 2011).

13 Of the 31 main countries Peru trades with, 17 are high-income countries. The value of exports to these countries represented $60 \%$ of total exports by value in 2007 .

Theoretical relationships between gdp cycle synchronization and specialization, trade and financial integration, and ptas

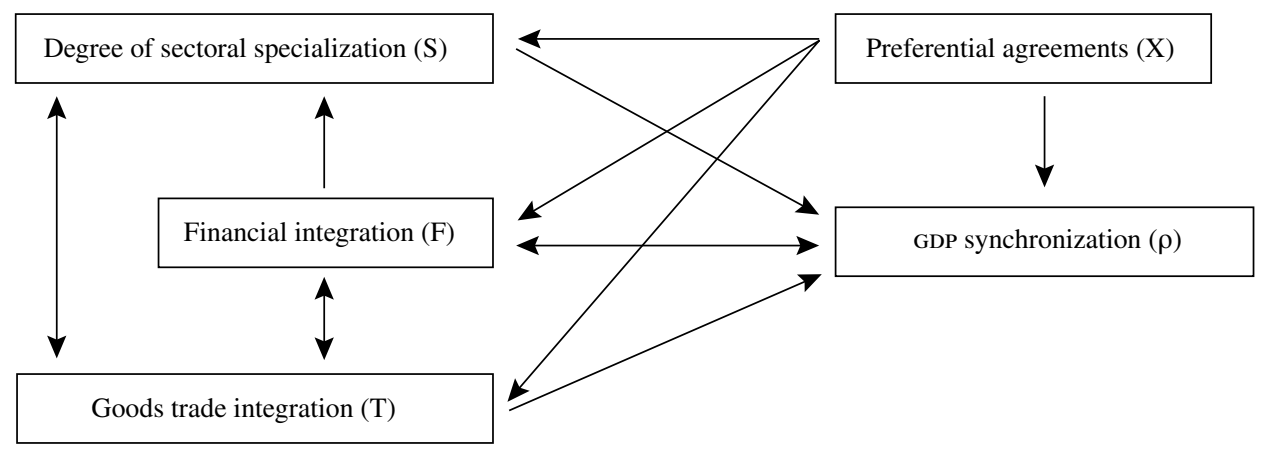

Source: prepared by the author.

GDP: gross domestic product.

PTAs: preferential trade agreements. 
integration of goods trade and financial integration would be expected to negatively affect the degree of synchronization between the GDP cycles of Peru and those of its main trading partners. In other words, all the $\alpha_{i}$ coefficients of equation (2.1) should be negative. Similarly, the degree of synchronization should negatively affect the degree of financial integration, i.e., $\delta_{1}$ should be negative and there should be an inverse relationship between the degree of specialization and the degree of trade integration, so that coefficients $\beta_{1}$ and $\gamma_{1}$ are less than zero (0). Meanwhile, given that foreign firms also predominate in Peru's commodity export sectors (Távara and Tello, 2010), there should be a complementary relationship between the degree of trade integration and the degree of financial integration and, consequently, the signs of coefficients $\beta_{2}$ and $\delta_{2}$ in equations (2.2) and (2.3), respectively, should be positive. By the same token, the indicator of financial integration should negatively affect the indicator of specialization, i.e., $\gamma_{2}$ should be less than zero $(0)$.

\section{IV}

\section{Estimations and findings: the case of Peru, 1982-2006 ${ }^{14}$}

Unlike the studies of Imbs (2004) and García-Herrero and Ruiz (2008), which estimate the system of simultaneous equations without considering the differences between countries, the estimates reported in table 1 present the coefficients and efficient estimators derived from the set of regressions carried out with the efficient three-stage ordinary least squares method (oLs-3), ${ }^{15}$ using panel data and incorporating the differences between countries ${ }^{16}$ in accordance with the formulation of Baltagi (2005). ${ }^{17}$

\footnotetext{
14 The empirical analysis in this section is exploratory in character, owing to the limitations of the information used in the present study. Consequently, the econometric evidence reported in this section cannot be treated as definitive findings. Rather, it may be interpreted as offering technical hypotheses with a likelihood of being correct, since the evidence (with all the shortcomings of the information available) supports them. Once the data limitations have been dealt with, the hypotheses formulated in this section can be appropriately verified. 15 Vector autoregression models (VARs) have not been considered owing to the limitations on the number of periods and for the sake of comparability with the estimates of García-Herrero and Ruiz (2008) and Imbs (2004).

${ }^{16}$ (Unreported) estimates were also carried out with oLs, two-stage oLs for each of the equations in the system and three-stage oLs for the whole system. In addition, two alternative measurements of the HodrickPrescott cycles were used: the errors of the quadratic regression in time for GDP (Peru's and its partner countries') and their respective GDP variation rates. In most cases, the results of all these estimates and measurements were similar to those reported here.

17 This method was selected to ensure that the variance and covariance matrices of the equation error components were defined as positive. The four equations were converted into a system of matrices $Y=Z \beta+\varepsilon$. According to Baltagi (2005), the estimator $\beta_{e}$ and the variance and covariance matrix $V$ of this efficient oLs-3 estimator are, respectively: $\beta_{e}=\left(Z^{*} P Z^{*}\right)^{-1} .\left(Z^{*} P y^{*}\right)$ and $V=\left(Z^{*}{ }^{\prime} P Z^{*}\right)^{-1}$, where $P=X^{*}\left(X^{*} X^{*}\right)^{-1}$ $X^{*}$, and $X^{*}=\Omega^{-1 / 2} \cdot(I \otimes X), Z^{*}=\Omega^{-1 / 2} \cdot Z ; y^{*}=\Omega^{-1 / 2} \cdot y ; E\left(\varepsilon \varepsilon^{\prime}\right)=\Omega, X$ is the matrix formed by the 40 predetermined model variables (including the constant and time).
}

The estimation was carried out in four steps: (i) estimation of oLs errors for each of the four equations in the system; (ii) estimation of the variance and covariance matrices of the random effects deriving from the differences between countries and the errors of each equation, ${ }^{18}$ using the oLs errors; (iii) determination of the Cholesky matrices of the inverses of the two previous matrices; ${ }^{19}$ and (iv) estimation of the coefficients of the system of equations using the oLs-3 method with instrumental variables. These variables are transformations of the exogenous variables of the system, previously multiplied by the Cholesky matrix of the inverse of the matrix of variances and covariances of error vector $\varepsilon$ of the system of equations. ${ }^{20}$

Eight regressions were carried out for each of the equations in the system derived by combining the six indicators representing the degrees of integration in trade, finance and specialization. The first column of table 1 shows the coefficients of the regressions that had the highest and most relevant degree of fit for each of the equations in the system. These coefficients correspond to indicators $\rho, T_{2}, F_{2}$ and $S_{1}$. The second column

\footnotetext{
${ }^{18}$ Where the error vector $\varepsilon=\left(\varepsilon_{1 t}, \varepsilon_{2 t}, \varepsilon_{2 t}, \varepsilon_{2 t}\right)$ is defined as: $\varepsilon_{j}=(I \otimes e)$ $\mu_{j}+v_{j} ; \mu_{j}$ is the random vector of the effects of the 31 countries $(N)$ for each equation $j ; v_{j}$ is the error vector of each equation; and $e$ is a vector whose size matches the number of years.

${ }^{19}$ The respective matrices are: $E\left(\mu \mu^{\prime}\right)=\Sigma_{\mu}$ and $E\left(v v^{\prime}\right)=\Sigma_{v}$.

20 This Cholesky matrix $\left(\Omega^{-1 / 2}\right)$ is a function of the two Cholesky matrices of the inverse matrices of the errors of the random country effects $\left(\Sigma_{u}^{-1 / 2}\right)$ and the errors of each equation $\left(\Sigma_{v}^{-1 / 2}\right)$. Specifically: $\Omega^{-1 / 2}=\sum_{1}^{-1 / 2} \otimes P+\sum_{v}^{-1 / 2} \otimes Q, \Sigma_{1}=N p \Sigma_{\mu}+\sum_{v}, N p=25$ is the number of years, $P=I \otimes J p, Q=I-P, J p$ is a square matrix of order $N p$ whose elements are equal to $1 / N p$.
} 
presents the percentage of positive and statistically significant coefficients from the eight estimations carried out for each equation. The third column shows the percentage of negative and statistically significant coefficients from the eight estimations carried out for each equation. These latter two columns show the degree of statistical robustness of the coefficients in the presence of variations in the indicators of financial, trade and specialization integration.
The last two rows of table 1 show the averages of the dependent variables and the coefficients of determination of the regressions in the first column.

Figure 2 shows the statistical results of the estimates of the coefficients that measure the relationships between the degrees of synchronization, trade and financial integration and the degree of sectoral specialization of the four-equation system described in table 1 . These results support the following hypotheses:

Peru: empirical relationships between gdp cycle synchronization and specialization, trade and financial integration, and ptas
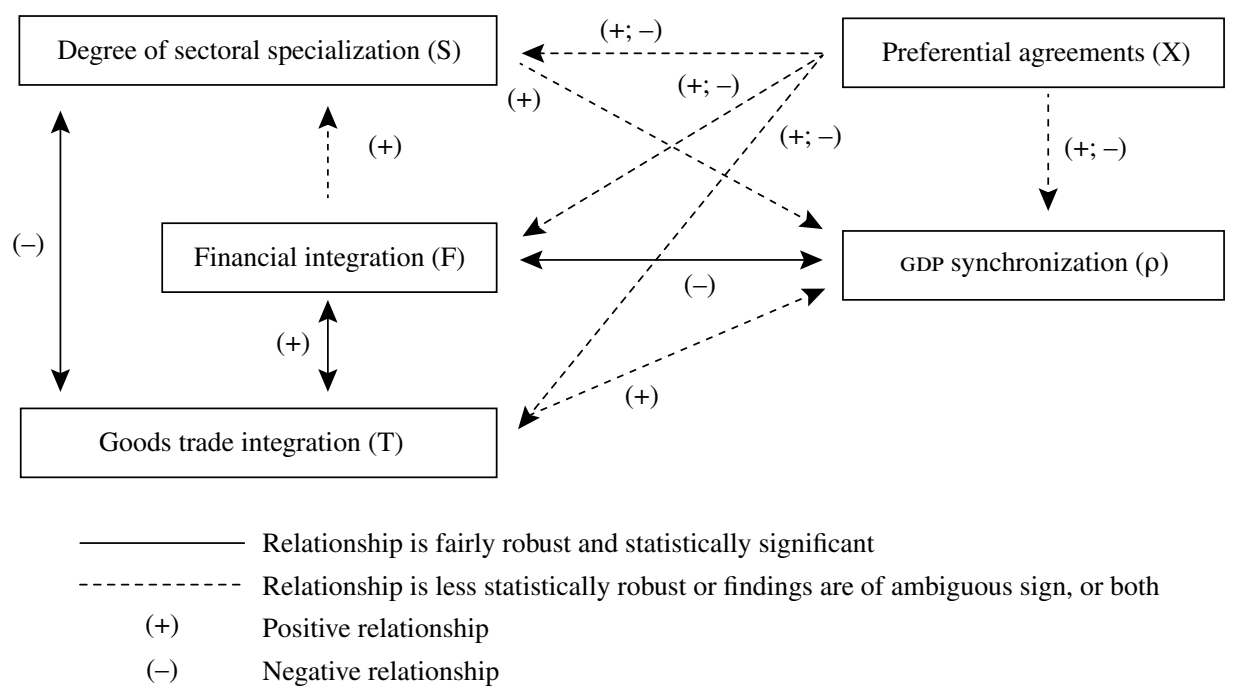

Source: prepared by the author. GDP: gross domestic product. PTAs: preferential trade agreements.

TABLE 1

Estimated coefficients of the equations for synchronization, trade integration, financial integration and specialization. Efficient panel three-stage ols method, Peru, 1982-2006

\begin{tabular}{|c|c|c|c|c|c|c|c|c|c|c|c|c|}
\hline \multirow[b]{2}{*}{ Factor } & \multicolumn{3}{|c|}{$\begin{array}{l}\text { (2.1) Degree of } \\
\text { synchronization }\end{array}$} & \multicolumn{3}{|c|}{$\begin{array}{l}\text { (2.2) Degree of } \\
\text { trade integration }\end{array}$} & \multicolumn{3}{|c|}{$\begin{array}{c}\text { (2.3) Degree of } \\
\text { financial integration }\end{array}$} & \multicolumn{3}{|c|}{$\begin{array}{l}\text { (2.4) Degree of } \\
\text { specialization }\end{array}$} \\
\hline & Coefficient & $\begin{array}{l}\text { Positive } \\
\text { sign } \\
(\%)\end{array}$ & $\begin{array}{c}\text { Negative } \\
\text { sign } \\
(\%)\end{array}$ & Coefficient & $\begin{array}{l}\text { Positive } \\
\text { sign } \\
(\%)\end{array}$ & $\begin{array}{c}\text { Negative } \\
\text { sign } \\
(\%)\end{array}$ & Coefficient & $\begin{array}{l}\text { Positive } \\
\text { sign } \\
(\%)\end{array}$ & $\begin{array}{c}\text { Negative } \\
\text { sign } \\
(\%)\end{array}$ & Coefficient & $\begin{array}{l}\text { Positive } \\
\text { sign } \\
(\%)\end{array}$ & $\begin{array}{l}\text { Negative } \\
\text { sign } \\
(\%)\end{array}$ \\
\hline \multicolumn{13}{|c|}{ 1. Basic variables } \\
\hline $\begin{array}{l}\text { Constant } \\
\left(\mathrm{T}_{2}\right)^{2} \mathrm{~T} \\
\left(\mathrm{~F}_{2}\right)^{2} \mathrm{~F} \\
\left(\mathrm{~S}_{1}\right)^{2} \mathrm{~S} \\
\rho\end{array}$ & $\begin{array}{l}0.1723 \\
-0.0412 \\
-0.0005 * \\
-0.0022\end{array}$ & $\begin{array}{l}50.0 \\
50.0 \\
25.0 \\
50.0\end{array}$ & $\begin{array}{r}12.5 \\
0.0 \\
62.5 \\
25.0\end{array}$ & $\begin{array}{l}-0.7989 \\
0.0026 \\
-0.0953^{* * *}\end{array}$ & $\begin{array}{l}37.5 \\
\\
62.5 \\
25.0\end{array}$ & $\begin{array}{r}37.5 \\
\\
0.0 \\
75.0\end{array}$ & $\begin{array}{c}120.2522 \\
70.97 * * *\end{array}$ & $\begin{array}{l}25.0 \\
75.0\end{array}$ & $\begin{array}{r}25.0 \\
0.0\end{array}$ & $\begin{array}{c}1.1847^{*} \\
-11.9^{* * *} \\
0.1099^{* * *}\end{array}$ & $\begin{array}{l}62.5 \\
12.5 \\
50.0\end{array}$ & $\begin{array}{r}0.0 \\
50.0 \\
25.0\end{array}$ \\
\hline
\end{tabular}


Table 1 (concluded)

\begin{tabular}{|c|c|c|c|c|c|c|c|c|c|c|c|c|}
\hline \multirow[b]{2}{*}{ Factor } & \multicolumn{3}{|c|}{$\begin{array}{l}\text { (2.1) Degree of } \\
\text { synchronization }\end{array}$} & \multicolumn{3}{|c|}{$\begin{array}{l}\text { (2.2) Degree of } \\
\text { trade integration }\end{array}$} & \multicolumn{3}{|c|}{$\begin{array}{l}\text { (2.3) Degree of } \\
\text { financial integration }\end{array}$} & \multicolumn{3}{|c|}{$\begin{array}{l}\text { (2.4) Degree of } \\
\text { specialization }\end{array}$} \\
\hline & Coefficient & $\begin{array}{c}\text { Positive } \\
\text { sign } \\
(\%)\end{array}$ & $\begin{array}{c}\text { Negative } \\
\text { sign } \\
(\%)\end{array}$ & Coefficient & $\begin{array}{l}\text { Positive } \\
\text { sign } \\
(\%)\end{array}$ & $\begin{array}{c}\text { Negative } \\
\text { sign } \\
(\%)\end{array}$ & Coefficient & $\begin{array}{c}\text { Positive } \\
\text { sign } \\
(\%)\end{array}$ & $\begin{array}{c}\text { Negative } \\
\text { sign } \\
(\%)\end{array}$ & Coefficient & $\begin{array}{l}\text { Positive } \\
\text { sign } \\
(\%)\end{array}$ & $\begin{array}{c}\text { Negative } \\
\text { sign } \\
(\%)\end{array}$ \\
\hline \multicolumn{13}{|c|}{ 2. Preferential trade agreements (PTAS) } \\
\hline CHI & -0.2664 & 25.0 & 12.5 & -0.8416 & 37.5 & 12.5 & 58.5489 & 25.0 & 0.0 & $-34.5^{*}$ & 0.0 & 12.5 \\
\hline DCHI & 0.0152 & 0.0 & 12.5 & 0.0411 & 0.0 & 12.5 & 2.2246 & 0.0 & 0.0 & 0.3258 & 0.0 & 0.0 \\
\hline TCHI & -0.1187 & 25.0 & 0.0 & -0.9615 & 12.5 & 0.0 & 9.4115 & 0.0 & 0.0 & -9.02 & 0.0 & 0.0 \\
\hline $\mathrm{AC}$ & 0.1998 & 25.0 & 37.5 & -0.1583 & 37.5 & 12.5 & 100.7731 & 25.0 & 0.0 & -14.8 & 0.0 & 0.0 \\
\hline DAC & 0.1608 & 12.5 & 12.5 & $-1.4274 * * *$ & 12.5 & 62.5 & 131.0232 & 25.0 & 0.0 & -24.98 & 0.0 & 0.0 \\
\hline TAC & -0.0086 & 12.5 & 12.5 & $0.0978^{* * *}$ & 62.5 & 12.5 & -11.7654 & 0.0 & 25.0 & 1.98 & 0.0 & 25.0 \\
\hline ACBR & 0.1122 & 62.5 & 12.5 & $-1.9626^{*}$ & 12.5 & 50.0 & -45.2430 & 0.0 & 0.0 & -15.11 & 0.0 & 50.0 \\
\hline DACBR & -0.0505 & 0.0 & 0.0 & -0.1411 & 0.0 & 0.0 & -19.5742 & 0.0 & 0.0 & -2.24 & 0.0 & 0.0 \\
\hline TACBR & 0.0045 & 0.0 & 12.5 & 0.0078 & 0.0 & 0.0 & 0.7367 & 0.0 & 0.0 & 0.22 & 0.0 & 0.0 \\
\hline ACAR & -0.1790 & 25.0 & 12.5 & 0.7787 & 37.5 & 12.5 & -48.1836 & 12.5 & 0.0 & 2.99 & 0.0 & 0.0 \\
\hline DACAR & -0.2381 & 12.5 & 12.5 & 0.0611 & 0.0 & 0.0 & -17.2676 & 0.0 & 0.0 & 5.06 & 0.0 & 0.0 \\
\hline TACAR & 0.0142 & 12.5 & 12.5 & -0.0127 & 12.5 & 0.0 & 1.4801 & 0.0 & 0.0 & -0.4001 & 12.5 & 0.0 \\
\hline ATPDEA & 0.0203 & 0.0 & 0.0 & 0.1829 & 12.5 & 0.0 & -93.2900 & 0.0 & 0.0 & 17.7 & 0.0 & 0.0 \\
\hline TATPDEA & 0.0001 & 0.0 & 0.0 & -0.0161 & 0.0 & 12.5 & 8.2432 & 0.0 & 0.0 & -1.5 & 0.0 & 0.0 \\
\hline UA & 0.0416 & 0.0 & 0.0 & 0.2443 & 0.0 & 0.0 & -71.8163 & 0.0 & 0.0 & 2.84 & 0.0 & 0.0 \\
\hline TUA & -0.0047 & 12.5 & 12.5 & -0.0232 & 0.0 & 0.0 & 6.6685 & 0.0 & 0.0 & -0.41 & 0.0 & 0.0 \\
\hline MA & -0.1460 & 12.5 & 12.5 & 0.7944 & 0.0 & 0.0 & -86.6109 & 0.0 & 0.0 & 9.11 & 0.0 & 0.0 \\
\hline TMA & 0.0100 & 12.5 & 12.5 & -0.0545 & 0.0 & 0.0 & 5.7680 & 0.0 & 0.0 & -0.58 & 0.0 & 0.0 \\
\hline \multicolumn{13}{|c|}{ 3. Control variables } \\
\hline Y & & & & $-0.1 \mathrm{E}-11$ & 37.5 & 12.5 & $-0.16 \mathrm{E}-10$ & 0.0 & 50.0 & $-0.34 \mathrm{E}-12$ & 0.0 & 50.0 \\
\hline Yp & & & & & & & $0.0354 * * *$ & 75.0 & 0.0 & & & \\
\hline Dif-Yp & & & & $0.33 \mathrm{E}-6 * * *$ & 37.5 & 62.5 & $-0.0329 * * *$ & 0.0 & 75.0 & -0.0001 & 0.0 & 0.0 \\
\hline DIF-INFLA & $-0.0001^{* * *}$ & 0.0 & 100.0 & & & & & & & & & \\
\hline RERb & & & & $0.0539 *$ & 50.0 & 12.5 & $3.8021^{* *}$ & 37.5 & 37.5 & & & \\
\hline TARIFF & & & & 0.0025 & 62.5 & 12.5 & 0.0451 & 25.0 & 50.0 & & & \\
\hline TIME & -0.0014 & 12.5 & 12.5 & $0.1057^{* * *}$ & 75.0 & 12.5 & $-4.8353^{*}$ & 0.0 & 37.5 & $-42.9715^{*}$ & 0.0 & 62.5 \\
\hline DIST & & & & $-0.0005^{* * *}$ & 37.5 & 50.0 & -0.0185 & 50.0 & 25.0 & -0.0020 & 0.0 & 50.0 \\
\hline LANG & & & & $-1.8506^{* *}$ & 0.0 & 87.5 & -3.8455 & 25.0 & 25.0 & -1.0539 & 0.0 & 37.5 \\
\hline BORDER & & & & $1.5706^{*}$ & 37.5 & 25.0 & -99.6162 & 0.0 & 25.0 & $33.801 * *$ & 75.0 & 0.0 \\
\hline SEA & & & & $1.8465^{* * * *}$ & 87.5 & 12.5 & $-185.50^{* *}$ & 25.0 & 50.0 & 16.3041 & 0.0 & 0.0 \\
\hline SIMILAR & & & & $0.858 \mathrm{E}-10^{* * *}$ & 37.5 & 62.5 & $0.248 \mathrm{E}-7^{* * * *}$ & 87.5 & 12.5 & $-0.27 \mathrm{E}-8 * * *$ & 0.0 & 100.0 \\
\hline AREA & & & & $1.396^{* * *}$ & 100.0 & 0.0 & $-177.33^{* * *}$ & 0.0 & 100.0 & $58.492^{* * *}$ & 62.5 & 0.0 \\
\hline $\mathrm{COL}$ & & & & 0.1558 & 25.0 & 25.0 & $412.55^{* * * *}$ & 75.0 & 0.0 & $-45.717 * *$ & 0.0 & 50.0 \\
\hline ISL & & & & 0.8559 & 12.5 & 37.5 & 46.62 & 0.0 & 25.0 & 3.556 & 50.0 & 0.0 \\
\hline North America & 0.1273 & 62.5 & 12.5 & & & & & & & & & \\
\hline Central America & 0.0915 & 37.5 & 37.5 & & & & & & & & & \\
\hline Southern Cone & $0.3526^{* * * *}$ & 62.5 & 37.5 & & & & & & & & & \\
\hline Other America & -0.0058 & 0.0 & 75.0 & & & & & & & & & \\
\hline European Union (EU) & $-0.232 * *$ & 25.0 & 75.0 & & & & & & & & & \\
\hline Asia & -0.201 & 37.5 & 37.5 & & & & & & & & & \\
\hline Dependent average $^{\mathrm{a}}$ & & 0.064 & & & 0.001 & 0.687 & & $3 \mathrm{E}-4$ & 77.190 & & -36.834 & -37.107 \\
\hline $\mathrm{R}^{2}$ & 0.635 & & & 0.944 & & & 0.676 & & & 0.885 & & \\
\hline
\end{tabular}

Source: prepared by the author.

Notes: All the regressions were based on 775 observations.

(i) With the exception of the first equation, where there is only one dependent, all the equations give the average of the two dependent options used: 2.2 (T1/T2); 2.3 (F1/F2) and 2.4 (S1/S2).

(ii)The estimated coefficients of each equation correspond to the regressions used in the indicators: $\rho, T_{2}, F_{2}$ and $S_{1}$.

a Average of the dependent variable. The nomenclature of the trade agreements and the control variables are described in section III of this article.

* $10 \%$ significance level,

** $5 \%$ significance level,

*** $1 \%$ significance level.

GDP: gross domestic product.

ACAR: partial scope economic complementation agreement between the Governments of Colombia, Ecuador, Peru and Venezuela, Andean Community member countries, and the Government of Argentina.

ACBR: partial scope economic complementation agreement between the Governments of Colombia, Ecuador, Peru and Venezuela, Andean Community member countries, and the Government of Brazil.

CHI: Chile-Peru Economic Complementation Agreement.

ATPDEA: Andean Trade Promotion and Drug Eradication Act.

UA: unilateral arrangement applying during periods of liberalization in the Peruvian economy.

MA: Uruguay Round multilateral agreement. 
H1: (degree of synchronization). When country effects are taken into account, the repercussions of trade integration and the degree of specialization as derived from the theory of comparative advantages based on natural resources are dominated by country shocks and have what are statistically quite robust ${ }^{21}$ effects on the degree of synchronization of gdp cycles between Peru and each of the 31 main trading partner countries. ${ }^{22}$ Thus, increases in trade integration, in the degree of similarity in sectoral structure, or both, lead to a greater degree of gdp cycle synchronization. Meanwhile, the effect of the degree of financial integration is more robust than the effects of the above, apparently exceeding the effect of inter-industry trade. Consequently, the higher the degree of financial integration, the lower the degree of cycle synchronization.

Specifically, the percentages of statistically significant positive coefficients for $T_{i}$ and $S_{i}(i=1,2)$ were $50 \%$, while in the case of negative coefficients for $F_{i}$ the figure was $62.5 \%$. One implication of this evidence is that the degree of synchronization of GDP cycles internationally has increased with the higher degree of trade integration, and it is therefore possible that the crises of 2008 and 2010 , the latter originating in the developed countries, may have affected Peru's GDP cycles.

H2: (interrelationships between basic variables). The evidence reveals a variety of interrelationships, most of them statistically robust, between degrees of synchronization, trade and financial integration and the degree of sectoral specialization. On the one hand, the interrelationships between trade integration and the degree of specialization, those between the degree of trade and financial integration, and those between the degree of synchronization and financial integration are statistically robust ${ }^{23}$ and two-directional. On the other, the effect of financial integration on the degree of specialization is less robust, with a positive relationship between the two indicators predominating.

The interrelationship between trade integration and financial integration is indicative of complementarity between the flow of goods and that of foreign investment. In other words, the relationship between the trade and

\footnotetext{
${ }^{21}$ I.e., when the percentage of statistically significant coefficients is $50 \%$ or greater.

${ }^{22}$ Note that the similarity between countries in their degree of sectoral specialization increases as $S_{i}$ approaches zero (0).

${ }^{23}$ A statistically robust bicausal relationship has been considered for the variables $(\mathrm{T}, \mathrm{F}, \mathrm{S})$ when the sum of the percentages of the (two) relevant coefficients that are statistically significant (of T, F or S) exceeds $100 \%$.
}

financial integration indicators for Peru in the 19822006 period was positive. At the same time, the greater difference in the degree of sectoral specialization resulted in a higher degree of trade integration, and this in turn increased the degree of sectoral specialization. It should be stressed again that the $S_{j t}$ indicators are negative values, and when these decrease this implies a larger differential in Peru's degree of specialization relative to its trading partner. The evidence is also robust as regards the effect of the cycle synchronization level on the degree of financial integration, although the effect of this on sectoral specialization is less robust. In this last case, however, financial integration has induced a greater similarity in the structures of production sectors. This finding is consistent with the higher degree of sectoral diversification of foreign investment in Peru. ${ }^{24}$

H3: (effect of preferential trade agreements). Virtually the majority of ptas have had no statistically robust effect on the degree of gdp cycle synchronization, trade and financial integration or sectoral specialization.

Only the Andean Community (AC) agreements and the economic complementation agreement between the $\mathrm{AC}$ and Brazil have had a statistically robust effect on the degree of trade integration and on the degrees of synchronization and sectoral specialization. With the latter agreement, it was country effects and not the agreement itself that affected these degrees. The dominant effect of the first agreement on the degree of integration was the permanent effect of the AC in creating more trade with its member countries.

H4: (effects of control variables on the degree of synchronization). The degree of synchronization of gdp cycles in Peru and its partner countries has been greater in the case of the countries of North America and the Southern Cone and lesser in the case of the countries of the European Union and the rest of the American continent.

In all these regions, the percentages of statistically significant coefficients were $62.5 \%$ or over. Furthermore, there is robust evidence that the degree of synchronization increases when the inflation differential between economies is reduced.

H5: (effects of the control variables on the degree of trade integration). The estimates reported in table 1 indicate

\footnotetext{
${ }^{24}$ In the 2001-2005 period, $31.7 \%$ of foreign investment flows went to the mining sector, $54.1 \%$ to the telecommunications sector and $13.8 \%$ to the service sector (Távara and Tello, 2010).
} 
that differences in countries' development levels or the degree of similarity (in gdp size) relative to countries that have traded with Peru, together with geographical characteristics (such as distance, geographical area and access to the sea) and cultural ones (such as language), have exercised a statistically significant and robust influence on the degree of trade integration between these countries.

The evidence shows that growing differences in development level or a growing degree of similarity in GDP size between countries increase market diversification and thus trade in goods and service between Peru and the trade partner. Again, trade restrictions (such as higher transport costs because partner countries are further from Peru or impose tariffs) have limited the degree of trade integration, whereas the geographical size, real exchange-rate and language variables have increased it. The effect of the other control variables on the degree of trade integration was not statistically robust.

H6: (effects of the control variables on the degree of financial integration). According to the predictions of the new endogenous growth theories, increasing differences in development levels between Peru and its trade partners have not promoted a greater degree of financial integration, and have consequently had a negative effect on the relative and absolute size of foreign investment flows from partner countries. Similarly, trading partner countries with a similar level of gdp to Peru or high levels of per capita gdp have had a positive effect on financial integration. With the exception of the distance, geographical area, colonial relationship and gdp size of Peru variables, the effect of the control variables on the degree of financial integration is not statistically robust.

Lucas (1990) provides theoretical and empirical arguments to support the thesis that foreign investment flows are greater between rich countries and smaller between rich and poor countries or between poor countries. The findings for Peru accord with these arguments, which assert that the availability of resources may not be enough for foreign producers to invest in poor countries. Endowments of human capital and technical know-how may also affect the profitability of countries' sectors, even those that do not possess comparative advantages. Accordingly, the degree of statistical robustness has been greater for partner countries with a higher degree of development than Peru's GDP size, which does not positively affect financial integration.

Meanwhile, there is reasonably robust evidence ${ }^{25}$ that financial integration is greater with partner countries that are distant from Peru (the North America, Europe and Asia regions, for example) ${ }^{26}$ and countries with which a colonial relationship has existed, and lower when tariffs or the geographical size of partner countries are larger.

As regards the effects of control variables on the degree of sectoral specialization, the statistical results show a number of inconsistencies with competitive advantage theories and the expected signs of the coefficients. Thus, for example, the evidence is statistically robust as regards the positive effects of similarity in GDP size between the trading partner country and Peru on the difference in these countries' degree of specialization. However, the size of the degree of similarity coefficient is very small. Similarly, there were positive effects on differences in sectoral structures, although statistical robustness was less for the colonial relationship and geographical distance of the partner country from Peru variables, and with Peruvian GDP. The magnitude of the coefficient of the variable is very small in this last case too. Again, the partner with border and partner's geographical area variables had a negative and statistically robust effect on the difference in degrees of sectoral specialization. The findings for the other variables were less robust.

\footnotetext{
25 Percentage of statistically significant coefficients of $50 \%$ or over.

26 More than $50 \%$ of Peru's exports by value go to the markets of the United States, the European Union, Japan and China.
} 
$\mathrm{V}$

\section{Conclusions and final considerations}

This exploratory study has presented a range of evidence and hypotheses concerning the interrelationships between the synchronization of Peru's total GDP cycle with the GDP cycles of 31 countries with which Peru trades $^{27}$ and the degree to which Peru is integrated in respect of trade, finance and sectoral specialization with these same countries. It has also estimated the repercussions of preferential trade agreements on these interrelationships. Subject to the limitations of the variables and measurements and the statistical fragility of the econometric method used, the evidence reported in this study reveals two main conclusions.

The first is that there is a statistically robust relationship between GDP cycle synchronization, financial and trade integration, and sectoral specialization. However, the two-way relationships that are most robust are those between the synchronization of GDP cycles and the degree of financial integration, between the latter and the degree of trade integration, and between this and the difference in the degree of sectoral specialization between Peru and its international trading partners. One implication of these interrelationships is that increases

\footnotetext{
27 These countries account for over $80 \%$ of Peru's total export and import flows.
}

in the relative size of Peru's trade flows relative to the real GDP of the 31 trading partner countries could heighten the degree of real GDP cycle synchronization between these countries and Peru. Again, albeit with less statistical robustness, increases in the differential between the degree of sectoral specialization in Peru and in its partner countries could also increase the level of these countries' GDP cycle synchronization. The second conclusion yielded by the evidence reported is that, in general, annualized PTAs have not had any statistically noticeable effect on the synchronization of international cycles, trade and financial integration or the degree of sectoral specialization.

Both conclusions suggest that the high level of sectoral specialization in the Peruvian economy (its tradable sector in particular) ${ }^{28}$ and increasing trade integration have amplified the impact of the international cycles of the country's leading trade partners on the Peruvian economy's GDP cycles. In consequence, economic policies designed to diversity production sectors, export markets, or both, may help to offset the adverse effects of international crises in the short and long term.

\footnotetext{
28 Where some $90 \%$ of the value exported is accounted for by agricultural and mining resource-intensive commodities.
} 
TABLE A1

Indicators of the degrees of synchronization, trade and financial integration and sectoral specialization in Peru and its main trading partners, 1982-2007

\begin{tabular}{|c|c|c|c|c|c|c|c|}
\hline Partner country & $\rho-\mathrm{HP}$ & $\mathrm{T} 1$ & $\mathrm{~T} 2$ & $\mathrm{~F} 1$ & $\mathrm{~F} 2$ & $\mathrm{~S} 1$ & S2 \\
\hline \multicolumn{8}{|l|}{ 1. Germany } \\
\hline 1982 & $-0.14(-)$ & $5.59(-)$ & $0.13(-)$ & $1.4(+)$ & $1090000(+)$ & $-51.85(-)$ & $-48.87(-)$ \\
\hline 2007 & $-0.33(+)$ & $3.6(-)$ & $0.1(-)$ & $2.53(+)$ & $5499231(+)$ & $-38.18(-)$ & $-35.81(-)$ \\
\hline \multicolumn{8}{|l|}{ 2. Argentina } \\
\hline 1982 & $0.14(+)$ & $10.62(+)$ & $0.32(+)$ & $15.95(-)$ & $1740000(-)$ & $-42.1(-)$ & $-39.55(-)$ \\
\hline 2007 & $0.54(+)$ & $15.32(+)$ & $0.6(+)$ & $-0.33(+)$ & $1223846(+)$ & $-28.44(-)$ & $-22.72(-)$ \\
\hline \multicolumn{8}{|l|}{ 3. Australia } \\
\hline 1982 & $-0.29(+)$ & $1.35(-)$ & $0.03(+)$ & $0.24^{\mathrm{a}}(+)$ & $106667^{\mathrm{a}}(+)$ & $-35.83(-)$ & $-35.83(-)$ \\
\hline 2007 & $0.38(+)$ & $1.16(+)$ & $0.04(+)$ & $0.2(-)^{\mathrm{b}}$ & $86154(-)^{\mathrm{c}}$ & $-25.6(-)$ & $-21.02(-)$ \\
\hline \multicolumn{8}{|l|}{ 4. Austria } \\
\hline 1982 & $0.03(+)$ & $1.31(+)$ & $0.04(+)$ & $0.52(+)$ & $50000(+)$ & $-45.82(-)$ & $-41.45(-)$ \\
\hline 2007 & $-0.24(-)$ & $1.11(-)$ & $0.04(-)$ & $0.9(+)$ & $203077(+)$ & $-31.9(-)$ & $-30.37(-)$ \\
\hline \multicolumn{8}{|l|}{ 5. Belgium } \\
\hline 1982 & $0.29(-)$ & $9.61(+)$ & $0.26(+)$ & $1.38(+)$ & $160000(+)$ & $-48.97(-)$ & $-48.97(-)$ \\
\hline 2007 & $-0.16(-)$ & $8.25(-)$ & $0.29(-)$ & $11.09(+)$ & $2967692(-)$ & $-35.59(-)$ & $-34.68(-)$ \\
\hline \multicolumn{8}{|c|}{ 6. Bolivia (Plurinational State of) } \\
\hline 1982 & $0.26(-)$ & $17.88(-)$ & $2.6(+)$ & $49.32(-)$ & $1500000(-)$ & $-23.25(+)$ & $-17.14(+)$ \\
\hline 2007 & $0.21(-)$ & $21.2(+)$ & $4.44(+)$ & $2.56(+)$ & $101539(+)$ & $-23.91(-)$ & $-16.08(-)$ \\
\hline \multicolumn{8}{|l|}{ 7. Brazil } \\
\hline 1982 & $0.19(+)$ & $6.98(-)$ & $0.18(+)$ & $5.45(-)$ & $1670000(-)$ & $-47.95(-)$ & $-45.52(-)$ \\
\hline 2007 & $0.73(+)$ & $8.61(+)$ & $0.28(+)$ & $15.95(+)$ & $12901923(+)$ & $-29.96(-)$ & $-28.55(-)$ \\
\hline \multicolumn{8}{|l|}{ 8. Canada } \\
\hline 1982 & $-0.2(-)$ & $2.66(-)$ & $0.06(+)$ & $11.36(-)$ & $3780000(-)$ & $-35.72(-)$ & $-35.72(-)$ \\
\hline 2007 & $0.1(+)$ & $3.19(+)$ & $0.1(+)$ & $11.67(+)$ & $9243846(+)$ & $-24.37(-)$ & $-22.36(-)$ \\
\hline \multicolumn{8}{|l|}{ 9. Chile } \\
\hline 1982 & $0.24(+)$ & $18.13(+)$ & $0.89(+)$ & $34.38(-)$ & $1690000(-)$ & $-28.62(-)$ & $-25.17(-)$ \\
\hline 2007 & $0.37(+)$ & $34.06(+)$ & $1.84(+)$ & $187.08(+)$ & $21656154(+)$ & $-22.88(-)$ & $-11.64(-)$ \\
\hline \multicolumn{8}{|l|}{ 10. China } \\
\hline 1982 & $-0.68(-)$ & $2.34(-)$ & $0.06(+)$ & $0.02^{\mathrm{d}}(-)^{\mathrm{e}}$ & $5000^{\mathrm{d}_{(-)}} \mathrm{f}^{\mathrm{f}}$ & $-92.73(-)$ & $-92.73(-)$ \\
\hline 2007 & $0.58(+)$ & $4.68(+)$ & $0.14(+)$ & $10.2(+)$ & $4698462(+)$ & $-78.85(-)$ & $-78.44(-)$ \\
\hline \multicolumn{8}{|l|}{ 11. Colombia } \\
\hline 1982 & $0.2(+)$ & $20.64(+)$ & $0.86(+)$ & $40.13(+)$ & $2560000(+)$ & $-36.78(-)$ & $-34.75(-)$ \\
\hline 2007 & $0.55(+)$ & $32.67(+)$ & $1.61(+)$ & $185.81(+)$ & $27371539(+)$ & $-25.76(-)$ & $-22.08(-)$ \\
\hline \multicolumn{8}{|c|}{ 12. Republic of Korea } \\
\hline 1982 & $-0.77(-)$ & $2.47(+)$ & $0.08(+)$ & $0.12^{\mathrm{e}_{(+)}}$ & $57692^{\mathrm{e}_{(+)}}$ & $-43.39(-)$ & $-43.15(-)$ \\
\hline 2007 & $0.12(-)$ & $4.53(+)$ & $0.15(+)$ & $2.94(+)^{\mathrm{g}}$ & $1723846(+) \mathrm{g}$ & $-36.87(-)$ & $-34.14(-)$ \\
\hline \multicolumn{8}{|l|}{ 13. Ecuador } \\
\hline 1982 & $0.55(-)$ & $39.52(-)$ & $3.21(-)$ & $30.25(-)$ & $1150000(-)$ & $-25.85(-)$ & $-23.33(-)$ \\
\hline 2007 & $0.25(-)$ & $44.38(+)$ & $4.35(+)$ & $28.16(+)$ & $2160769(+)$ & $-26.08(+)$ & $-12.98(-)$ \\
\hline \multicolumn{8}{|l|}{ 14. Spain } \\
\hline 1982 & $-0.11(+)$ & $3.48(-)$ & $0.09(+)$ & $6.14(+)$ & $1320000(+)$ & $-43.34(-)$ & $-37.85(-)$ \\
\hline 2007 & $-0.3(+)$ & $4.15(+)$ & $0.13(+)$ & $259.41(+)$ & $143273462(+)$ & $-30.17(-)$ & $-27.48(-)$ \\
\hline \multicolumn{8}{|l|}{ 15. United States } \\
\hline 1982 & $-0.62(-)$ & $5.76(-)$ & $0.14(-)$ & $3.5(+)$ & $11380000(+)$ & $-43.37(-)$ & $-43.37(-)$ \\
\hline 2007 & $0.1(+)$ & $4.31(-)$ & $0.12(-)$ & $10.4(+)$ & $95065000(+)$ & $-34.2(-)$ & $-31.88(-)$ \\
\hline \multicolumn{8}{|l|}{ 16. Finland } \\
\hline 1982 & $0.2(-)$ & $2.12(-)$ & $0.07(+)$ & $0.05^{\mathrm{g}}(-)^{\mathrm{h}}$ & $3333^{\mathrm{g}_{(-)}} \mathrm{h}$ & $-40.51(-)$ & $-37.32(-)$ \\
\hline 2007 & $0.08(+)$ & $2.44(+)$ & $0.09(+)$ & $0.18(+)$ & $47692(+)$ & $-29.62(-)$ & $-26.04(-)$ \\
\hline \multicolumn{8}{|l|}{ 17. France } \\
\hline 1982 & $0.07(+)$ & $1.59(-)$ & $0.04(+)$ & $9.85(+)$ & $5890000(-)$ & $-45.09(-)$ & $-45.09(-)$ \\
\hline 2007 & $-0.43(+)$ & $1.37(-)$ & $0.04(-)$ & $2.43(+)$ & $328462(+)$ & $-34.01(-)$ & $-32.57(-)$ \\
\hline \multicolumn{8}{|l|}{ 18. Italy } \\
\hline 1982 & $0.21(-)$ & $3.66(-)$ & $0.09(+)$ & $3.35(+)$ & $1460000(+)$ & $-45.28(-)$ & $-43.65(-)$ \\
\hline 2007 & $-0.18(+)$ & $3.09(-)$ & $0.09(-)$ & $5.12(+)$ & $7206154(+)$ & $-32.91(-)$ & $-31.64(-)$ \\
\hline
\end{tabular}

Continues overleaf 
Table A1 (concluded)

\begin{tabular}{|c|c|c|c|c|c|c|c|}
\hline Partner country & $\rho-\mathrm{HP}$ & $\mathrm{T} 1$ & $\mathrm{~T} 2$ & $\mathrm{~F} 1$ & $\mathrm{~F} 2$ & $\mathrm{~S} 1$ & $\mathrm{~S} 2$ \\
\hline \multicolumn{8}{|l|}{ 19. Japan } \\
\hline 1982 & $-0.23(-)$ & $5.93(-)$ & $0.14(-)$ & $5.19(-)$ & $5750000(-)$ & $-49.62(-)$ & $-45.07(-)$ \\
\hline 2007 & $-0.16(-)$ & $3.45(-)$ & $0.09(-)$ & $0.98(+)$ & $3425385(+)$ & $-35.93(-)$ & $-33.42(-)$ \\
\hline \multicolumn{8}{|l|}{ 20. Luxembourg } \\
\hline 1982 & $-0.3(+)$ & $44.46(+)$ & $5.31(+)$ & $169.16(-)$ & $4970000(-)$ & $-48.97(-)$ & $-48.97(-)$ \\
\hline 2007 & $-0.34(+)$ & $33.87(-)$ & $4.47(-)$ & 6.03(-) & 691 923(-) & $-37.62(-)$ & $-35.08(-)$ \\
\hline \multicolumn{8}{|l|}{ 21. Mexico } \\
\hline 1982 & $0.78(-)$ & $3.93(-)$ & $0.11(+)$ & $0.4(-)$ & $80000(-)$ & $-36.02(-)$ & $-36.02(-)$ \\
\hline 2007 & $-0.1(+)$ & $5.36(+)$ & $0.18(+)$ & $19.88(+)$ & $16684231(+)$ & $-26.07(-)$ & $-24.8(-)$ \\
\hline \multicolumn{8}{|c|}{ 22. New Zealand } \\
\hline 1982 & $0.07(-)$ & $8.58(-)$ & $0.37(+)$ & $0.24^{\mathrm{i}_{(+)}} \mathrm{j}^{\mathrm{j}}$ & $100000^{\mathrm{i}}(+)^{\mathrm{j}}$ & $-32.98(-)$ & $-32.63(-)$ \\
\hline 2007 & $0.3(+)$ & $5.7(-)$ & $0.29(-)$ & $2.37(+)$ & $263462(-)$ & $-22.56(-)$ & $-20.54(-)$ \\
\hline \multicolumn{8}{|l|}{ 23. Panama } \\
\hline \multicolumn{8}{|l|}{ 24. Netherlands } \\
\hline 1982 & $-0.09(-)$ & $8(-)$ & $0.2(+)$ & $5.23(+)$ & $890000(+)$ & $-40.28(-)$ & $-40.28(-)$ \\
\hline 2007 & $-0.12(-)$ & $6.16(-)$ & $0.19(-)$ & $112.24(+)$ & $52818077(+)$ & $-28.37(-)$ & $-26.96(-)$ \\
\hline \multicolumn{8}{|l|}{ 25. Portugal } \\
\hline 1982 & $0.27(-)$ & $1.38(+)$ & $0.05(+)$ & $-0.237(-)$ & $-100007(-)$ & $-31.52(-)$ & $-28.63(-)$ \\
\hline 2007 & $-0.34(+)$ & $1.31(-)$ & $0.06(-)$ & $8.21(-)$ & $1427692(-)$ & $-23.78(-)$ & $-18.86(-)$ \\
\hline \multicolumn{8}{|c|}{ 26. United Kingdom } \\
\hline 1982 & $-0.63(-)$ & $3.91(-)$ & $0.09(+)$ & $2.44(+)$ & $1240000(+)$ & $-44.06(-)$ & $-44.06(-)$ \\
\hline 2007 & $0.1(-)$ & $2.61(-)$ & $0.08(-)$ & $75.78(+)$ & $109920385(+)$ & $-31.85(-)$ & $-30.5(-)$ \\
\hline \multicolumn{8}{|l|}{ 27. Singapore } \\
\hline 1982 & $0.53(-)$ & $1.49(+)$ & $0.12(+)$ & $4.86^{\mathrm{k}}(+)$ & $869565^{1}(+)$ & $-54.03(-)$ & $-54.03(-)$ \\
\hline 2007 & $0.41(+)$ & $1.77(-)$ & $0.12(-)$ & $21.63(+)^{1}$ & $4750000(+)^{1}$ & $-40.72(-)$ & $-40.21(-)$ \\
\hline \multicolumn{8}{|l|}{ 28. Sweden } \\
\hline 1982 & $-0.05(-)$ & $4.04(-)$ & $0.11(+)$ & $7.92(+)$ & $1030000(+)$ & $-43.48(-)$ & $-43.48(-)$ \\
\hline 1982 & $0.08(+)$ & 4.98(-) & $0.14(+)$ & $40.58(-)$ & $5140000(-)$ & $-48.72(-)$ & $-48.72(-)$ \\
\hline 2007 & $-0.15(-)$ & $3.29(-)$ & $0.11(-)$ & $28.41(+)$ & $8023077(+)$ & $-35.37(-)$ & $-34.85(-)$ \\
\hline \multicolumn{8}{|l|}{ 30. Uruguay } \\
\hline 1982 & $0.49(+)$ & $2.71(+)$ & $0.25(+)$ & $120.15(-)$ & $4080000(-)$ & $-35.07(-)$ & $-29.72(-)$ \\
\hline 2007 & $0.54(+)$ & $3.67(+)$ & $0.46(+)$ & $109.27(+)$ & $6653846(+)$ & $-24.75(-)$ & $-18.44(-)$ \\
\hline \multicolumn{8}{|c|}{ 31. Venezuela (Bolivarian Republic of) } \\
\hline 1982 & $0.1(+)$ & 13.41(-) & $0.43(+)$ & $17.24(-)$ & $1750000(-)$ & $-52.66(-)$ & $-46.05(-)$ \\
\hline 2007 & $0.37(+)$ & $22.65(+)$ & $1.03(+)$ & $1.27(-)$ & $93846(-)$ & $-44.32(-)$ & $-40.57(-)$ \\
\hline
\end{tabular}

Source: prepared by the author.

Notes: The indicators r-HP, T1, T2, F1, F2, S1 and S2 represent cycle synchronization and, with two indicators apiece, trade integration, financial integration, and specialization, as defined in section III.

For indicators T1 and F1, the figures are expressed with E-04 and E-06 decimals, respectively.

${ }^{\mathrm{a}}$ Figure for 2002. ${ }^{\mathrm{b}}$ Figure for 2003-2007. ${ }^{\mathrm{c}}$ Figure for 2003-2007. ${ }^{\mathrm{d}}$ Figure for 1983. ${ }^{\mathrm{e}}$ Figure for 1984-1990. ${ }^{\mathrm{f}}$ Figure for $1983-1990$. ${ }^{\mathrm{g}}$ Figure for 1995-2007. ${ }^{\mathrm{h}}$ Figure for $1985-1990 .{ }^{\mathrm{i}}$ Figure for 1985. ${ }^{\mathrm{j}}$ Figure for 1986-1990. ${ }^{\mathrm{k}}$ Figure for 2004. ${ }^{\mathrm{l}}$ Figure for 2005-2007. The indicator for the degree of specialization, $S_{i}$, is multiplied by 100 ; the range is from $-200 \%$ to $0 \%$. The signs in parentheses for the degrees of synchronization correspond to the sign of the growth rates of the correlation coefficients for 1982-1990 (for the 1982 row) and 19912006 (for the 2007 row). Thus, a positive sign in 1982 means that the correlation coefficient increased in the 1982-1990 period. The S1 information is for 1982-2006. The signs in parentheses for the rest of the indicators are the annual rates of change in each indicator in the 1982-1990 and 1991-2007 periods. 


\section{Bibliography}

Aghion, Ph. and A. Banerjee (2005), Volatility and Growth, New York, Oxford University Press.

Ambler, S., E. Cardia and C. Zimmermann (2002), "International transmission of the business cycle in a multi-sector model", European Economic Review, vol. 46, No. 2, Amsterdam, Elsevier.

Backus, D., P. Kehoe and F. Kidland (1993), "International business cycle: theory and evidence", nber Working Paper, No. 4493, Cambridge, Massachusetts, National Bureau of Economic Research. Published also in Frontiers of Business Cycle Research, Thomas Cooley (ed.), Princeton, Princeton University Press, 1995.

(1992), "International real business cycles", Journal of Political Economy, vol. 100, No. 4, Chicago, University of Chicago Press, August.

Baltagi, N. (2005), Econometric Analysis of Panel Data, West Sussex, John Wiley \& Sons.

Baxter, M. (1995), "International trade and business cycle", Handbook of International Economics, vol. 3, G. Grossman and K. Rogoff (eds.), Amsterdam, Elsevier.

Calderon, C., A. Chong and E.H. Stein (2007), "Trade intensity and business cycle synchronization: are developing countries any different?", Journal of International Economics, vol. 71, No. 1, Amsterdam, Elsevier, March.

Calvo, G. and E. Mendoza (2000), "Rational contagion and the globalization of securities markets", Journal of International Economics, vol. 51, No. 1, Amsterdam, Elsevier.

Canova, F. and H. Dellas (1993), "Trade interdependence and the international business cycle", Journal of International Economics, vol. 34, No. 1-2, Amsterdam, Elsevier.

Coe, D.T. and E. Helpman (1995), "International R\&D spillovers", European Economic Review, vol. 39, No. 5, Amsterdam, Elsevier.

Darvas, Z. and G. Vadas (2005), "A new method for combining detrending techniques with application to business cycle synchronization of the new EU members", mnb Working Papers, No. 2005/5, Budapest, Magyard Nemzeti Bank.

De Gregorio, J. and J. Lee (2003), "Growth and adjustment in East Asia and Latin America", Working Papers, No. 245, Santiago, Chile, Central Bank of Chile.

Edwards, S. (2007), "Crises and growth: a Latin American perspective", nber Working Paper, No. 13019, Cambridge, Massachusetts, National Bureau of Economic Research.

Fidrmuc, J. and I. Korhonen (2009), "The impact of the global financial crisis on business cycles in Asian emerging economies", cesifo Working Paper, No. 2710, Munich, CESifo Group Munich.

Frankel, J.A. and A.K. Rose (1998), "The endogeneity of the optimum currency area criteria", The Economic Journal, vol. 108, No. 449, Royal Economic Society.

García-Herrero, A. and J. Ruiz (2008), "Do trade and financial linkages foster business cycle synchronization in a small economy?", Working Paper, No. 810, Madrid, Bank of Spain.

Heathcote, J. and F. Perri (2002a), "Financial autarky and international business cycles", Journal of Monetary Economics, vol. 49, No. 3, Amsterdam, Elsevier.

(2002b), "Financial globalization and real regionalization", nber Working Paper, No. 9292, Cambridge, Massachusetts, National Bureau of Economic Research.

Hodrick, R.J. and E.C. Prescott (1997), "Postwar US business cycles: an empirical investigation", Journal of Money, Credit, and Banking, vol. 29, No. 1, Blackwell Publishing.

Imbs, J. (2004), "Trade, finance, specialization and synchronization", Review of Economics and Statistics, vol. 86, No. 3, Cambridge, Massachusetts, The MIT Press.

INEI (National Institute of Statistics and Informatics) (2009) [online] http://www.inei.gob.pe.
Kalemli-Ozcan, S., B. Sørensen and O. Yosha (2003), "Risk sharing and industrial specialization: regional and international evidence", American Economic Review, vol. 93, No. 3, Nashville, Tennessee, American Economic Association, June.

(2001), "Economic integration, industrial specialization, and the asymmetry of macroeconomic fluctuations", Journal of International Economics, vol. 55, No. 1, Amsterdam, Elsevier.

Kollman, R. (2001), "Explaining international comovements of output and asset returns: the role of money and nominal rigidities", Journal of Economics Dynamics and Control, vol. 25, No. 10, Amsterdam, Elsevier.

Kose, M. and K. Yi (2006), "Can the standard international business cycle model explain the relation between trade and comovement?", Journal of International Economics, vol. 68, No. 2, Amsterdam, Elsevier.

(2002), "The trade comovement problem in international macroeconomics", Staff Reports, No. 155, New York, Federal Reserve Bank of New York.

(2001), "International trade and business cycles: is vertical specialization the missing link", American Economic Review, vol. 91, No. 2, Nashville, Tennessee, American Economic Association.

Krugman, P. (1993), "Lesson of Massachusetts for EMU", The Transition to Economic and Monetary Union in Europe, F. Giavazzi and F. Torres (eds.), New York, Cambridge University Press.

Lichtenberg, F. and B. van Pottelsberghe (1998), "International R\&D spillovers: a comment", European Economic Review, vol. 42, No. 8, Amsterdam, Elsevier.

Loayza, N. and V. Hnatkovska (2003), "Volatility and growth", Washington, D.C., World Bank, unpublished.

Lucas, R. (1990), "Why doesn't capital flow from rich to poor countries?", American Economic Review, vol. 80, No. 2, Nashville, Tennessee, American Economic Association, May.

Mendoza, E. (2002), "Credit, prices and crashes: business cycles with a sudden stop", Preventing Currency Crises in Emerging Markets, S. Edwards and J. Frankel (eds.), Chicago, University of Chicago Press.

Stockman, A.C. (1988), "Sectoral and national aggregate disturbances to industrial output in seven European countries", Journal of Monetary Economics, vol. 21, No. 2-3, Amsterdam, Elsevier.

Távara, J. and M.D. Tello (2010), "Productive development policies in Latin American countries: the case of Peru, 1990-2007', Working Paper, No. 129, Washington, D.C., Inter-American Development Bank.

Tello, M.D. (2011), "Barreras no arancelarias y protección interna y externa de los productos transables agropecuarios: el caso del Perú, 2000-2008", Política comercial, crisis externa e impactos sobre el sector agropecuario peruano, W. Mendoza and M.D. Tello (eds.), Lima, Consorcio de Investigación Económica y Social (CIES).

(2009a), Arreglos preferenciales comerciales y crecimiento económico en América Latina, Lima, CENTRum Católica.

(2009b), "Crecimiento económico, arreglos preferenciales comerciales y choques externos en el Perú, 1950-2007", Crisis internacional: impactos y respuestas de política económica en el Perú, F. Jiménez and O. Dancourt (eds.), Lima, Catholic University of Peru.

UnCTAD (United Nations Conference on Trade and Development) (2009), unctad Handbook of Statistics [online] http:// stats.unctad.org/Handbook/TableViewer/tableView. aspx?ReportId=2061.

United Nations (2009), "UN Comtrade" [online] http://comtrade. un.org/.

White, H. (1980), "A heteroskedasticity-consistent covariance matrix estimator and a direct test for heteroskedasticity", Econometrica, vol. 48, No. 4, New York, Econometric Society. 